\title{
VISI ISLAM DALAM AGAMA DAN PERADABAN DALAM PERSPEKTIF MARSHALL G.S HODGSON
}

\author{
Farida Ulvi Na'imah \\ Hukum Keluarga Islam, Institut Pesantren KH. Abdul Chalim \\ Email: Faridaulvi@yahoo.com
}

\begin{abstract}
This study describes Marshall G. Hodgson's thinking about the study of Islamic history studies in his work entitled The Venture of Islam. The research used in this study is analytical descriptive, which is a study that examines Marshall G.S Hodgson's thinking about Islamic history studies then parses and identifies the patterns of thought. According to Marshall G.S. Hodgson the history of Islam is the result of the ever-changing setting shaped by the Islamic tradition. In addition, it is also the result of a process of accomodation or acculturation from other pre-existing cultural traditions. Based on this view, and in the context of conversations about Islamic civilization, Marshall G. S. Hodgson emphasized the importance of seeing cultural continuity occurring at the level of religion, expressed by Muslims. Marshall G.S. Hudgson in seeing the reality of Islam in the world classifies in three forms of Islamic phenomena as the object of study. First, the phenomenon of Islam as a doctrine (Islamic), second, the phenomenon when the doctrine enters and processes in a cultural society (Islamicate) and manifests itself in a particular social and historical context. And thirdly, when Islam became a phenomenon of the political "World" in state institutions (Islamdom).
\end{abstract}

Keywords: Vision, Religion, and Civilization

\begin{abstract}
Abstrak
Penelitian ini mendeskripsikan pemikiran Marshall G.S Hodgson tentang kajian Islamic history studies dalam karyanya yang berjudul The Venture of Islam. Penelitian yang dipakai dalam penelitian ini adalah deskriptis analitis, yakni penelitian yang mengkaji pemikiran Marshall G.S Hodgson tentang Islamic history studies kemudian mengurai dan mengidentifikasi corak pemikirannya. Menurut Marshall G. S. Hodgson sejarah Islam merupakan hasil dari setting yang selalu berubah yang dibentuk oleh tradisi Islam. Selain itu, ia juga merupakan hasil dari sebuah proses akomodasi atau akulturasi dari tradisi kultural lain yang telah ada sebelumnya. Berdasarkan pandangan ini, dan dalam konteks perbincangan mengenai peradaban Islam, Marshall G. S. Hodgson menekankan pentingnya melihat kesinambungan kultural yang terjadi pada tingkat agama, yang diekspresikan oleh umat Islam. Marshall G.S. Hudgson dalam melihat realitas Islam di dunia mengklasifikasikan dalam tiga bentuk fenomena Islam sebagai sasaran studi. Pertama, fenomena Islam sebagai doktrin (Islamic), kedua, fenomena ketika doktrin itu masuk dan berproses dalam sebuah masyarakatkultural (Islamicate) dan mewujudkan diri dalam konteks sosial dan kesejarahan tertentu. Dan ketiga, ketika Islam menjadi sebuah fenomena "dunia Islam" yang politis dalam lembagalembaga kenegaraan (Islamdom).
\end{abstract}

Kata kunci: Visi, Agama, dan Peradaban

\section{PENDAHULUAN}

Perkembangan ilmu sejarah sejarah dalam Islam tidak dapat dipisahkan dari perkembangan budaya secara umum yang berlangung sangat cepat. Dalam bidang 
politik, hanya dalam satu abad lebih sedikit, Islam sudah menguasai Spanyol, Afrika Utara, Syiria, Palestina, Semenajung Arabia, Irak, sebagian Asia, Persia, Afganistan, dan lain-lain. Kebangkitan Islam itu melahirkan sebuah imperium, mengalahkan dua imperium besar yang sudah ada sebelumnya : Persia dan Bizantium. Sejalan dengan menanjaknya imperium besar ini, umat Islam juga menggalakkan pengembangan ilmu pengetahuan, baik dalam bidang agama maupun umum. Perkembangan ilmu pengetahuan itu semakin dipercepat dengan terjadinya kontak-kontak pemikiran dan budaya antara orang-orang Arab Islam dengan bangsa yang telah ditaklukannya.

Seiring dengan perkembangan budaya dan peradaban Islam itulah ilmu sejarah dalam Islam lahir dan berkembang. Ketika umat islam sudah mencapai kemajuan dalam penulisan sejarah, tidak ada bangsa lain waktu itu yang menulis sejarah seperti halnya kaum muslimin. Namun dewasa ini, seiring dengan kemajuan ilmu pengetahuan dunia, usaha mempelajari sejarah perdaban Islam dalam kenyataannya bukan hanya dilaksanakan oleh kalangan umat Islam saja, melainkan dilaksanakan juga oleh orangorang di luar kalangan umat Islam. Islamic history studies di kalangan umat Islam sendiri, tentunya mempunyai tujuan yang berbeda dengan tujuan Islamic history studies yang dilakukan oleh orang-orang di luar kalangan umat Islam.

Di kalangan umat Islam, Islamic history studies bertujuan untuk memahami dan mendalami serta membahas ajaran-ajaran Islam agar mereka dapat melaksanakan dan mengamalkan secara benar, serta menjadikannya sebagai pegangan dan pedoman hidup (way of life). Sedangkan di luar kalangan umat Islam, seperti di Negara-negara Barat, Islamic history studies bertujuan untuk mempelajari seluk beluk agama dan praktek-praktek keagamaan yang berlaku di kalangan umat Islam, yang semata-mata sebagai ilmu pengetahuan. Namun, sebagaimana halnya dengan ilmu pengetahuan pada umumnya, maka ilmu pengetahuan tentang seluk beluk agama dan praktek-praktek keagamaan Islam tersebut bisa dimanfaatkan atau digunakan untuk tujuan-tujuan tertentu, baik yang bersifat positif maupun yang bersifat negatif.

\section{BIOGRAFI MARSHAL G.S HODGSON}

Salah satu sarjana-sarjana Barat yang tampaknya amat tertarik dengan dinamika umat Muslim di dunia ini adalah Marshal G.S. Hodgson, warga Amerika 
yang telah berkarya dengan sebuah karya besar The Venture of Islam, telah menyampaikan pesan dengan seobyektif mungkin tentang Islam dan peradabannya serta pengaruhnya terhadap peradaban Barat.

Nama lengkapnya adalah Marshall Goodwin Simms Hodgson (11 April 1922 10 Juni 1968), adalah seorang Studi Islam akademis dan sejarawan dunia di University of Chicago. Dia merupakan ketua Interdisipliner Komite Pemikiran Sosial di Chicago. Sebagaimana dijelaskan sebelumnya, Hodgson adalah penulis buku fundamental, The Venture Islam yang secara universal diakui sebagai sebuah karya yang fundamental dalam studi sejarah Islam dan Peradaban Muslim. Meskipun Dia tidak menerbitkan secara ekstensif selama hidupnya, ia telah menjadi sejarawan Islam dari Amerika yang paling berpengaruh.

Marshall Hodgson meninggal secara mendadak pada tanggal 10 Juni 1968 dalam usia 47 tahunsebelum karyanya The Venture of Islam diselesaikannya. Karyanya ini, pada awalnya merupakan outline singkat yang beberapa babnya terdiri hanya dari dua atau tiga halaman. Pada waktu yang bersamaan dia juga sedang menggarapmsebuah sejarah dunia. ${ }^{1}$ Menurut Reuben W. Smith awalnya buku ini hanya untuk memenuhi kebutuhan mata kuliah sejarah peradaban Islam di Universitas Chicago. $^{2}$

Marshall Hodgson tentu bukan satu satunya sejarawan yang dilahirkan oleh Universitas Chicago, tetapi ia adalah seorang guru dari kajian sejarah baik dunia maupun Islam yang selain dipengaruhi oleh rekan-rekannya juga mempunyai pengaruh yang formatif terhadap visi historis yang dikembangkan di Universitas ini pada masa sesudahnya. Pengaruh yang muncul dari geliat akademis seorang Hodgson sangat besar dari pemikiran kesejarahan baik Islam maupun dunia dikalangan sejarawan kontemporer di mana saja. ${ }^{3}$

Pendirian Hodgson terhadap Islam secara jujur diakuinya bahwa beliau adalah seorang Kristen yang beriman, sebab itu, baik dalam The Venture of Islam atau dalam karyanya yang lain, ia tidak melakukan formulasi-formulasinya atas dasar agama yang

\footnotetext{
1 Marshall Hodgson, The Venture of Islam: Iman dan Sejarah Dalam Peradaban Islam, Terjemah Mulyadi Kartanegara (Jakarta: Paramadina, 1999), ix-x

${ }^{2}$ Ibid., $\mathrm{x}$

${ }^{3}$ Hodgson, The Venture, Vol 1, xviii
} 
mewakili agama Kristen begitu saja, tetapi didasarkan pada pertimbangan pertimbangan yang telah dikembangkan dalam disiplin modern kajian kajian agama. ${ }^{4}$

\section{PEMBAHASAN}

Dalam menulis buku The Venture of Islam yang dianggap sebagai sebuah karya magisterial pikiran sejak publikasi pada awal 1975, Hudgson menginterpretasikan sejarah perkembangan peradaban Islam dari sebelum kelahiran Muhammad ke tengah abad kedua puluh, didahului dengan penelitian dan disertai dengan analisis terhadap peristiwa-peristiwa di masa silam, terutama dalam menggali jawaban terhadap pertanyaan "mengapa dan apa jadinya" tentang sejarah perdaban Islam. Sehingga dapat dikatakan, penulisan sejarah perdaban Islam yang dilakukan oleh Hudgson dikatagorikan studi sejarah kritis.

Ide pokok buku ini sesungguhnya sudah dipersiapkan Marshall G.S Hodgson sejak usia 19 tahun. Buku ini dipilah atas tiga bagian: (1) pengantar pada pengkajian peradaban Islam yang meliputi transelerasi bahasa (Arab, Persia, Turki, Utsmaniah, dan Urdu), metodologi analisis peradaban, pembahasan dasar tentang istilah-istilah fenomenologi "Arabic", "Allah", "syari'ah", "Riwayat Hadits", (2) prolog umum, yakni visi Islam dalam agama dan dalam peradaban; dan (3) membentangkan lahirnya tatanan baru Islam berdasarkan tinjauan peran Islam sampai pada pergolakan masuknya Islam dalam gelanggang politik kenegaraan. Namun dalam makalah ini, penulis hanya mengupas tentang Visi Islam dalam agama dan peradaban yang terdapat dalam kata pengantar buku The Venture of Islam The Consciece and History In a World Civilization: The Classical Age of Islam, Vol. 1.

Sejarah Islam merupakan hasil dari setting yang selalu berubah yang dibentuk oleh tradisi Islam. Selain itu, ia juga merupakan hasil dari sebuah proses akomodasi atau akulturasi dari tradisi kultural lain yang telah ada sebelumnya. Berdasarkan pandangan ini, dan dalam konteks perbincangan mengenai peradaban Islam, Marshall G. S. Hodgson menekankan pentingnya melihat kesinambungan kultural yang terjadi pada tingkat agama, yang diekspresikan oleh umat Islam. Sebab peradaban, bagi Hodgson, merupakan pengelompokan yang relatif luas dari kebudayaan-kebudayaan

\footnotetext{
${ }^{4}$ Ibid., xix
} 
yang saling berkaitan. Dan dalam peradaban Islam, jalinan berbagai kebudayaan itu disatukan dan diikat oleh kepercayaan Islam cita-cita ilahiah tentang transformasi menuju kehidupan yang saleh.5

Kehadiran Islam telah membuat perbedaan dan perubahan besar dalam tatanan masyarakat dunia. Pada satu sisi, kehadiran agama Islam telah menciptakan masyarakat dengan karakteristik yang disebut Islami. Pada sisi lainnya, Islam juga melestarikan tradisi-tradisi yang lebih awal ke dalam bentuk-bentuk baru di bawah nama peradaban Islam. Cita-cita transformasi Islam ini setidaknya bisa dilihat dalam Al-Qur'an: "Engkau telah menjadi umat terbaik yang pernah dimunculkan untuk umat manusia, seraya menganjurkan kebaikan dan melarang keburukan, dan yang percaya kepada Tuhan". ${ }^{6}$ Meski demikian, tak ada penafsiran seragam dan gambaran ideal tentang bagaimana rupa dari "masyarakat terbaik" tersebut.7 Oleh karena itu, sejarah Islam merupakan ikhtiar terus-menerus umat Islam untuk membangun masyarakat yang baik sesuai dengan visi Islam tersebut.

Penjelasan di atas menegaskan satu hal penting bahwa Islam adalah agama yang menyejarah. Ia tumbuh di atas peradaban umat-umat sebelumnya. Islam menyerap berbagai tradisi agama yang telah ada dan memberinya bentuk baru yang lebih sesuai dengan nilai-nilai normatif Islam. Demikianlah sejarah Islam kemudian terbentuk. Ia merupakan jalinan antara realitas nyata yang dihadapi oleh kaum Muslim, sekaligus sebagai rekaman atas perjuangan umat Islam dalam menafsirkan sumber pokok Islam, yaitu Al-Qur'an dan hadis. Kedua teks tersebut menjadi sentral dalam sejarah Islam. Ini karena begitu pentingnya teks, sehingga teks menjadi semacam paradigma yang mengarahkan hampir seluruh kehidupan umat Islam dalam sepanjang perjalanan sejarahnya. Karenanya, sejarah Islam selalu mengorbit kepada teks dalam dua sisi yang bertautan. Satu sisi berupa penafsiran dari teks menuju konteks atau realitas. Sisi lainnya adalah penyesuaian realitas terhadap nilai-nilai normatif yang terkandung dalam teks Islam.

\footnotetext{
${ }^{5}$ Marshall G.S. Hodgson, The Venture of Islam Conscience and History in a World Civilization, Vol. 1, The Classical Age Of Islam (Chicago: The University of Chicago Press,1974), 118-136.

${ }^{6}$ QS. Ali Imran (2): 110

${ }^{7}$ Ibid., 99-100.
} 
Menurut Hodgson, Al Qur'an merupakan koleksi wahyu yang Tuhan turunkan kepada Muhammad kata per kata dan al Qur'an diterima secara harfiah.8 Sebagai pegangan utama umat Islam, Al-Quran mengandung nilai-nilai normatif yang menjadi sumber pokok dan pedoman dasar dalam setiap aspek kehidupan masyarakat Muslim. Selain itu, Al-Quran juga mengandung kisah masa lalu manusia yang merupakan tamsil untuk diambil sebagai pelajaran dan teladan. Tentang ini Al-Qur'an menyebutkan:9 "Sesungguhnya pada kisah-kisah mereka terdapat pengajaran bagi orang-orang yang mempunyai akal. Al-Quran itu bukanlah cerita yang dibuat-buat, akan tetapi membenarkan (kitab-kitab) yang sebelumnya dan menjelaskan segala sesuatu sebagai petunjuk dan rahmat bagi kaum yang beriman". Bahkan, pentingnya sejarah Islam tak bisa dilepaskan dari kenyataan bahwa sebagian besar dari isi kandungan Al-Qur'an adalah tentang sejarah.10

Sementara hadis adalah riwayat riwayat dari kata-kata dan perbuatan Muhammad yang diriwayatkan oleh sahabat-sahabatnya.11 Hadis memiliki otoritas yang hampir sama dengan Al-Quran. Pada masa Nabi hidup, segala bentuk persoalan keagamaan tidak perlu diperdebatkan, karena semua persoalan dapat dipertanyakan langsung kepada Nabi. Kepentingan akan hadis baru dirasakan setelah Rasulullah wafat. Masalah-masalah yang menyangkut hukum tidak semuanya dapat dirujuk kepada Al-Quran secara langsung, karena tidak semua ayat dalam Al-Quran secara jelas menetapkan suatu hukum. Dalam konteks inilah hadis menjadi sumber pokok kedua setelah Al-Qur'an, sebagai perincian, penegas, maupun penerang ketentuanketentuan dalam Al-Qur'an. Bisa dipahami bila kemudian muncul pemikiran bahwa sejarah Islam tak bisa dilepaskan dari keberadaan Al-Qur'an dan hadis. Bahkan, historiografi Islam bermula dari penulisan hadis-hadis Nabi.

Sementara mengenai Islam, setidaknya terdapat dua pengertian yang sejauh ini banyak dipakai para sarjana. Secara terminologis, kata islam (dengan huruf kecil), dalam bahasa Arab berarti tindakan penyerahan diri kepada Tuhan. Menjadi muslim berarti menerima pertanggungjawaban pribadi atas norma-norma tindakan yang

\footnotetext{
${ }^{8}$ Hodgson, The Venture, Vol. 1, 101.

${ }^{9}$ QS. Yusuf (12): 111.

${ }^{10}$ Taufik Abdullah [dkk., eds.], Ensiklopedi Tematis Dunia Islam: Pemikiran dan Peradaban (Jakarta: Ichtiar Baru Van Hoeve, 2002), 266.

${ }^{11}$ Hodgson, The Veture, Vol, 1, 101.
} 
dipandang memiliki kekuatan ketuhanan. Kata islam dengan demikian merujuk pada bentuk spiritual batin dari seorang pribadi yang punya kehendak baik. Pengertian "Islam" (dengan huruf besar) kemudian merujuk secara lebih umum pada keseluruhan pola sosial dari sistem pemujaan dan kepercayaan yang bagi para pemeluknya yang saleh, tumbuh dari Islam pribadi dan dari para pemeluk individualnya.12 Inilah Islam dalam pengertian historisnya. Dengan pengertian tersebut, maka sejarah Islam sesungguhnya terkait dengan berbagai aspek kehidupan umat Muslim yang diinsipirasikan dan diarahkan oleh nilai-nilai spiritual Islam. Oleh karena itu, selain aspek normatif dan historis ajaran Islam, faktor penting yang turut membentuk historiografi Islam adalah adanya kesadaran sejarah (historisitas) umat Islam. Historisitas merupakan tingkat kesadaran masyarakat mengenai masa lalu, yang terlihat dari paradigma berpikir masyarakat tentang pentingnya pengungkapan masa lalu secara obyektif.

Dalam mengkaji peradaban Islam, Hodgson selalu mengingatkan untuk memberi perhatian yang besar pada masyarakat dan kebudayaan sebagai konteksnya, dalam hal ini umat Muslim. Kebudayaan Islam menjadi penting karena Ia mewakili aspirasi dan pencapaian kreatif yang paling tinggi dari beratus juta manusia. Dengan mengkaji mereka, menurut Hodgson, kita jadi mengenal dan memahami diri kita sebenarnya dengan lebih baik, dulu dan sekarang sebagai manusia.13 Pada titik inilah, studi Islam meniscayakan sebuah kajian yang mendalam dan komprehensif atas sejarah Islam. Tanpanya, studi Islam akan berakhir hanya sebatas kajian atas teologi atau doktrin-doktrin Islam yang terlepas dari konteks sejarah masyarakatnya. Dengan memasukkan bahasan sejarah Islam, maka studi Islam akan meliputi kajian masyarakat Islam dan peradaban yang berhasil dibangunnya, dalam dialektika dengan kebuda $\neg$ aankebudayaan lainnya di dunia.

Menurut Hodgson, dari semua pola budaya umat manusia sepanjang sejarah, pola budaya Islam adalah yang paling mendekati keberhasilan menjadi pola budaya dunia. ${ }^{14}$ Di samping itu, di dalam buku ini juga dijelaskan bahwa Islam dalam konteks

\footnotetext{
${ }^{12}$ Hodgson, The Venture Vol. 1, 101.

${ }^{13}$ Hodgson, The Venture Vol. 1, 141-142.

14 Marshall G.S. Hodgson membagi sejarah Islam menjadi tiga periode. Pertama, periode klasik. Periode ini dimulai sejak lahirnya Islam (670-an M.) hingga runtuhnya tradisi pemerintah absolut (945
} 
sejarah tidak pernah tercatat menghilangkan budaya lokal. sebagaimana dikemukakan oleh Hodgson, dalam sejarah kelahirannya Islam selalu tampil dalam format dialogdialog agama dan dialog-dialog peradaban. ${ }^{15}$ Islam hadir memberi warna baru dan mengisinya dengan nilai atau ajaran yang lebih universal dan bernuansa spiritualitas. Nabi Muhammad saw di Arab mengganti tradisi haji yang berbau jahiliah dengan ajaran Islam. Bahkan, mengubah perilaku buruk yang membudaya di Makkah dan Madinah menjadi sebaliknya. ${ }^{16}$ Fakta historis itulah yang kemudian oleh Marshall G.S. Hodgson disebut Islamicate, budaya yang bercorak Islam. Hodgson dalam studi peradaban Islam, menganjurkan dalam melihat realitas Islam di dunia harus bisa membedakan antara Islam sebagai doktrin (Islamic) dan fenomena ketika doktrin itu masuk dan berproses dalam sebuah masyarakat-kultural yang disebut "Islamicate". Kemudian juga harus melihat konteks sosial dan kesejarahan, khususnya saat Islam menjadi sebuah fenomena "dunia Islam" yang politis dalam kenegaraan yang disebut dengan "Islamdom". ${ }^{17}$ Islamicate merupakan karakteristik pendekatan Islam pada wilayah kekuasaan, terutama Timur Tengah. Bermula dari sebuah agama, kemudian berkembang menjadi sebuah sistem yang menata kehidupan masyarakat, dan meliputi segenap aspek kehidupan.

Kata "Islam" oleh sebagian orang selalu dikonotasikan sebagai sebuah wujud yang utuh antara doktrin dan praktik yang dilakukan oleh para pemeluknya. Padahal dalam kajian yang lain, terutama dalam tinjauan sejarah, hubungan doktrin dan praktik peradabannya, terutama di masing-masing wilayah, masih mengandung "jarak" yang sangat memungkinkan untuk bisa dibedakan dan dibicarakan secara objektif.

M.). Kedua, periode pertengahan. Periode ini dimulai sejak pertengahan abad ke kesepuluh ( 945 M.) hingga abad kelima belas ( 1503 M.), yakni ketika kemajuan belahan dunia Barat seimbang dengan kemajuan dunia Timur dan tumbuhnya peradaban internasional. Ketiga, periode modern. Periode ini dimulai sejak abad kelima belas, ketika kerajaan Islam terwakili oleh tiga kerajaan besar: Safawi di Persia, Mughal di India, dan kerajaan Turki (ottoman) di Turki, hingga sekarang. Baca Marshal G.S. Hodgson, The Venture of Islam: Conscience and History in a World Civilization, Vol 1-3 (Chicago: The University of Chicago Press, 1977).

${ }^{15}$ Hodgson, Marshall G.S, The Venture of Islam : Iman dan Sejarah dalam Peradaban Islam, Buku Pertama Lahirnya sebuah Tatanan Baru, Terj. Mulyadhi Kartanegara (Jakarta: Paramadina, 2002).

${ }^{16}$ Ibid.

${ }^{17}$ Marshall G.S. Hodgson, The Venture of Islam : Conscience and History in a World Civilization, The Expansion of Islam in The Middle World, Volume 2 (Chicago : The University of Chichago, 1974), hal 8-11. 
Islam memiliki karakteristik global, dapat diterima dalam setiap ruang dan waktu. Namun pada sisi yang lain, saat ia memasuki kawasan wilayah, karakteristik globalnya seolah-olah hilang melebur ke dalam berbagai kekuatan lokal yang dimasukinya. Dengan demikian, Islam seringkali dipandang sebagai agama yang memiliki kesatuan dalam keragamannya kesatuan dan universalitas Islam dalam aspekaspek teologi dan spiritualnya, sementara lokalitas keragamannya berada dalam polapola penerapan dengan variasi kultural masing-masing.

Marshall G.S. Hudgson menganjurkan kepada setiap pengkaji Islam, terutama dalam melihat realitas Islam di dunia, harus bisa membedakannya dalam tiga bentuk fenomena Islam sebagai sasaran studi. Pertama, fenomena Islam sebagai doktrin (Islamic), kedua, fenomena ketika doktrin itu masuk dan berproses dalam sebuah masyarakat-kultural (Islamicate) dan mewujudkan diri dalam konteks sosial dan kesejarahan tertentu. Dan ketiga, ketika Islam menjadi sebuah fenomena "dunia Islam" yang politis dalam lembaga-lembaga kenegaraan (Islamdom) yang bertolak dari konsep dār al-Islām. ${ }^{18}$

Sekalipun dikatakan demikian, kedua fenomena terakhir (islamicate dan islamdom) tidak bisa memberikan jaminan secara pasti bahwa seluruh perilaku umatnya berjalan persis sesuai dengan teks doktrin. Dengan kata lain, islamicate dan islamdom merupakan fenomena Islam yang telah terlontar dalam kancah sejarah dalam konteks struktural tertentu pada ruang waktu yang berbeda dan mengikatnya. Dengan demikian kajian kawasan dunia Islam yang dimaksud dalam buku ini berada dalam wilayah riset islamicate dan islamdom. Dengan hadirnya buku ini, cara pandang yang salah terhadap Islam bisa semakin berkurang. Cara pandang yang menyejajarkan Islam dengan terorisme dan gerakan-gerakan radikalisme akan semakin terbantahkan. Adanya keragaman praktik keislaman yang disebabkan oleh kultur dan politik menjadi alasan bahwa sesungguhnya Islam tidak bisa dipersalahkan.

Apabila membaca kawasan Islam atau peradaban Islam dengan kacamata Hodgson maka akan jelas terlihat bagaimana beragamnya Islam ketika hadir dalam

\footnotetext{
${ }^{18}$ Menurutnya, dalam konteks kesarjaanaan modern, menggunakan term 'Islam' atau 'Islamic' terlalu sederhana (too casually) untuk menyebut 'agama' atau untuk menebut keseluruhan masyarakat dan budaya yang secara historis diasosiasikan dengan istilah tersebut. Marshall G.S. Hodgson, The Venture of Islam, hal 3-11
} 
kawasan lainnya. Meskipun jauh dari tempat lahirnya Islam, komunitas Islam di kawasan-kawasan tertentu tidak jauh beda dalam pelaksanaan keislamannya dan tidak ada istilah yang paling asli dan tidak asli. Karena yang menilai keislaman jelas bukan manusia.

\section{KESIMPULAN}

Menurut Marshall G. S. Hodgson sejarah Islam merupakan hasil dari setting yang selalu berubah yang dibentuk oleh tradisi Islam. Selain itu, ia juga merupakan hasil dari sebuah proses akomodasi atau akulturasi dari tradisi kultural lain yang telah ada sebelumnya. Berdasarkan pandangan ini, dan dalam konteks perbincangan mengenai peradaban Islam, Marshall G. S. Hodgson menekankan pentingnya melihat kesinambungan kultural yang terjadi pada tingkat agama, yang diekspresikan oleh umat Islam. Marshall G.S. Hudgson dalam melihat realitas Islam di dunia mengklasifikasikan dalam tiga bentuk fenomena Islam sebagai sasaran studi. Pertama, fenomena Islam sebagai doktrin (Islamic), kedua, fenomena ketika doktrin itu masuk dan berproses dalam sebuah masyarakat-kultural (Islamicate) dan mewujudkan diri dalam konteks sosial dan kesejarahan tertentu. Dan ketiga, ketika Islam menjadi sebuah fenomena "dunia Islam" yang politis dalam lembaga-lembaga kenegaraan (Islamdom).

\section{DAFTAR PUSTAKA}

Hodgson, Marshall, The Venture of Islam: Iman dan Sejarah Dalam Peradaban Islam, Terjemah Mulyadi Kartanegara (Jakarta: Paramadina, 1999).

Taufik Abdullah [dkk., eds.], Ensiklopedi Tematis Dunia Islam: Pemikiran dan Peradaban (Jakarta: Ichtiar Baru Van Hoeve, 2002). 